\title{
On Symbolic Significance of Characters in Lord of the Flies
}

\author{
Xiaofang Li \& Weihua Wu \\ School of Foreign Languages \\ Yan'an University \\ Yangjialing 716000, China \\ E-mail:1xf0318@126.com.
}

\begin{abstract}
The characters in Lord of the Flies possess recognizable symbolic significance, which make them as the sort of people around us. Ralph stands for civilization and democracy; Piggy represents intellect and rationalism; Jack signifies savagery and dictatorship; Simon is the incarnation of goodness and saintliness. All of these efficiently portray the microcosm of that society.
\end{abstract}

Keywords: William Golding, Characters, Symbolic significance

\section{Introduction}

Lord of the Flies is written by famous contemporary novelists William Golding (1911-1993), who won the Nobel Prize for Literature in 1983. Since its publication in 1954, the novel has become the best sellers and has been studied in schools and universities nearly all over the world.

Such success has great relationship with the author's unique writing style-he puts symbolism in a delicate blending of fable, allegory and adventure story. Lord of the Flies depicts the transformation into savagery of a group of English schoolboys stranded on a desert island without adult supervision in the aftermath of a plane crash. At the beginning, the children manage to take care of themselves and expect the hope of rescue. However, the boys are soon controlled by the fear in their hearts. The island community breaks up into two rival groups, represented respectively by Ralph, who insists on civilized values and the hope of rescue; Jack, who wants to enjoy the freedom and benefits of hunting on the island. Eventually, the paradise-like island is destroyed in fire of cannibalism. The schoolboys are rescued and reverted from savages to obedient schoolboys on the arrival of an English Cruiser when he was in his business of fighting another cruiser.

\section{Symbolic Significance of Characters}

The characters in Lord of the flies possess recognizable traits that make them individuals as the sort of people that everyone has known in school, work and society, and become convincingly embodiments of particular aspects of human nature.

\subsection{Ralph-Civilization and Democracy}

Ralph, fair-haired, athletically built, good-looking and from a prosperous, middle-class family, is the charismatic protagonist of Lord of the Flies. He leads and accommodates to others in terms of the fondly cherished, moderate English tradition. Ralph, the representative of civilization and democracy, lives by rules, acts peacefully, and follows moral commands and values the good of the group, who dramatically reveals the condition of civilization and democracy in Golding's time.

Driven by his instinct of civilization and democracy, Ralph wants to set up a civilized utopia for all the boys on the island. He blows the conch and summons the deserted children together. He suggests the boys making a chief by voting, which shows his thought of law, order and democracy. After he is elected as the chief, he makes rules of speaking; Ralph tries to have the boys preserve the civilized living principles.

Although he is the only one who worries over the welfare of the other boys and his instinct of civilization survives longer than any other character, he is not resolute and decisive when facing the problems. Since he becomes a leader, Ralph is determined to seek way for rescue by keeping a signal fire for attracting a passing ship. But with the appearance of beast from water, Ralph is confused in despair to ask a sign from that ruined world. In "Beast from Air", after their exploration, his intelligence is crippled by fear, so they keep a signal on the rock instead on the top of the 
mountain. When Jack challenges his authority, Ralph does not give a firm counterattack, even wants to give up the position of chief, and takes part in the feast of Jack and killing of Simon. To a great degree, Ralph helps the expanding of savagery.

If we set the story against the social background during World War II, it is easy for us to find the boys in the novel from the politicians at that time. "If Ralph is Chamberlain and Jack Hitler, Roger is the Gestapo."(Kirstin Olsen: 14) This kind of comparison is seemingly surprising to us, but as a matter of fact there's something reasonable in it. Chamberlain was British Prime Minister before the war, who took a policy of appeasement towards Hitler's aggression. It's his diplomatic policy that should be partly responsible for Hitler's expansion, which finally caused the greatest tragedy in the history of the world. There is something similar between Ralph and Chamberlain. Ralph is the chief among the boys, but when Jack challenges his authority, he in most cases is reluctant to fight against Jack. He has such a capability but he fails to make use of it. He could challenge Jack physically and defeat him once and for all; he could lend Piggy more assistance in forming a coalition. Yet he does nothing and even thinks to "give up being chief". His attitude towards Jack to some degree makes all the things go wrong and gets Jack's group becomes more ferocious and violent.

But, to our relief, Ralph is aware of the reason of the savagery at the end of the novel. When he is hunted by the "hunters", Ralph has found the lord of the flies - the Beelzebub, He smashes the Beelzebub, and he grows mature and begins to be aware of the reason So, at the end, when the officer rescues him, Ralph weeps, "for the end of innocence, the darkness of man's heart, and the fall through the air of the true, wise friend called Piggy"(William Golding:223).Though he fails in striving for the returning of the values of civilization, it's not only his fault. It is the failure of mankind to deal with the forces of evil. Some critics say that Golding is a sheer pessimist. No, one of his hopes lies on Ralph's self-awareness.

\subsection{Piggy_-Intellect and Rationalism}

Piggy is the embodiment of intellect and rationalism. He firstly senses the seriousness of their life on the island and he reminds Ralph of their serious situation by using three words of death in succession when Ralph takes it for granted that they will be rescued soon. In addition, he firstly suggests that they should do something such as collecting the scattered boys. And he gives the information of conch and teaches Ralph the ways of blowing. Piggy, too, is the first to recognize that life entails making certain choices and establishing certain priorities. And Piggy firstly suggests lighting a small smoke and avoiding the danger of setting fire on the forest and the necessary wood for the signal fire when they firstly light the signal fire, but the enthusiastic action overwhelms his advice. Piggy even thinks about creating a sundial by which they can know time. Piggy takes a scientific and rational attitude towards life. When the fear of beast confuses them, Piggy speaks that life is scientific (William Golding: 92).

Piggy suggests the real fear is the fear of people. His forward-looking imagination sees things very clearly as they will be. He senses the evil people, but he can do nothing. When the "hunters" worship their God-the lord of the flies, the science and rationalism keep him from participating in the superstition of the other boys and keep him standing with Ralph. What is important is that Piggy shares the out-of-date confidence of Ballantyne that common sense can master any problem, and he believes that most people, given the chance, are as sensible as him. In the period of overwhelming war, Piggy's confidence is as resolute as that of an old man, so he is like an old father compared to the boys on the island. He always stands with Ralph and he believes the confidence of Ballantyne.

Piggy's near-sight implies that his intelligence is limited. Simon is aware that man is heroic and sick, but for Piggy man is not ill, man just has a foolish but corrigible habit of following Jack (fascist) if Jack should be taking Piggy's sensible advice. He does not realize that fascism overwhelms and will kill anything they want to.

Piggy, representative of intellect and rationalism, is like a sacrificial pig impaled on the sharpen stick since anarchy and animalism is in dominion. There is no rescue.

\subsection{Jack-Savagery and Dictatorship}

Jack, Ralph's antagonist, represents the brilliant world of hunting, tactics, fierce exhilaration, skill and dictator, the authoritarian man-of-power who enters the scene like a sergeant. Jack is the strong-willed, egomaniacal boy, who is the novel's prime representative of the instinct of savagery and violence. From his appearance, Jack is always associated with shadows and obscurity, and his frustrated angry eyes reveal his mind. From the start of the story, he claims to hunt for meat. Actually his argument is a filmy pretext for the fact that he needs blood. He wants to share the pleasure of conquest and killing more than eating meat as he recalls, "He has outwitted a living thing, imposed their will upon it, and taken away its life like a satisfying drink".( William Golding, 76.)

When the restraints of civilization no longer take effect, the evil reveals its true face. Jack devises the painted mask of the hunter, with which the recall of civilization covers. Then he is liberated from shame and self-consciousness and becomes the leader of the anonymous mob of murderous savages. With the expanding of the bloodlust, Jack becomes more and more savage and violent. Under the enforcement of savagery, he has already forgotten the distinction between animals and men, as do primitives. He leads the hunters not only to kill pigs but also to kill his companions such as 
Simon, Piggy and nearly Ralph. As Alastair Niven puts it, "Jack represents more completely than anyone else in the novel the theme of 'reversion to savagery' and he finds that behind the disguise of paint and mask he can assume a more self-confident personality" (Alastair Niven, 48).

On the other hand, Jack is a totalitarian, an authoritarian man-of-power who despises assemblies and conch, and becomes an absolute ruler of his tribe in the end. When he appears at the assembly, he shows the desire of power and authority as he claims with simple arrogance "I ought to be chief, because I'm chapter chorister and head boy. I can sing C sharp" (William Golding 23). His privileged choir-school background has undoubtedly taught him much about the necessity of hierarchies; including the notion that head boy from such a school ought to be a top man anywhere. Although he fails in the vote, it does not defeat him. He continuously rages and breaks the democratic procedures of the assembly. The way to get things done, he believes, is to compel, not ask, to terrorize, not persuade. At last, Jack becomes the real dictator who enjoys the worship of his "hunters" and rules them by terror. After he successfully controls the island, he is the undisputed lord of the feast, "where he sits upon his log-throne, painted and garlanded, sat there like an idol. There were piles of meat on green leaves near him, and fruit, and coco-nut shells full of drink." and "power lay in the brown swell of his forearms: authority sat on his shoulder and chattered in his ear like an ape."(William Golding, 164-65)

The sense of power has given him a newly sinister quality behind his paint. He abuses his power by his arbitrary beating of Wilfred, violent stealing of fire, cruel robbing of spec from Piggy, forceful enlisting of Sam and Eric and delirious killing of Piggy. What's more, to satisfy his need of dictatorship, Jack has sacrificed the island, which means sacrificing themselves, to kill Ralph. Their behavior reaches the climax of terrorism and frenzy.

The character of Jack not only shows us how the primitive desire and actions are released where there are no restrictions of civilization but also what an dictator would have done or would do when driven by his evil power and lust for blood.

\subsection{Simon-Goodness and Saintliness}

If Ralph stands at one end of a line, representing civilization, and Jack stands at other end of the line, representing savagery, where does Simon stand? The answer is that, unlike all the other boys, Simon stands on a different plane from every other character in the novel. Why? During World War II, William Golding witnessed the expenditure of human ingenuity in the old ritual of war. As the illusions of his earlier rationalism and humanism fell away, he concluded, "the shape of society must depend on the ethical nature of the individual and not on any political system however apparently logical or respectable"(James R. Baker: 23) and he illustrated it in Lord of the Flies. In a way, Simon represents the future ideal personality of Golding. Therefore, Simon stands higher than any other characters.

Simon represents saintliness and a kind of innate, spiritual human goodness that is deeply connected with nature and, in its own way, as primal as Jack's evil instinct. The other characters in the novel abandon moral behavior as soon as civilization no longer imposes upon them; they are not innately moral but have simply been conditioned to act morally in the adult world with the threat of punishment for misdeed. Of all the other children on the island, only Simon acts morally not out of some guilt or shame but out of his inherent value. His affection for the other boys never wanes like a saint.

In the eyes of William Golding, Simon is a saint as he has described, "Simon is a Christ-figure... a lover of mankind, a visionary" (Alastair Niven: 49). When the other boys are busy satisfying releasing their nature restrained by civilization, such as playing in the water, eating the rich ripe fruit, going on hunting, Simon explores the forest, marveling at the beauty and harmony of the natural world and discovering a secret place of his own as his sanctum, where he acknowledges the truth by intuition.

Simon is endowed with insight into the unchanging nature of human beings and communities, which is also why he is so affirmative a figure on Beelzebub's island among sadists and savages. When the children on the island have got themselves into a hell of mess, Simon "thought of the beast, there rose before his inward sight the picture of human at once heroic and sick".(William Golding:113) This embodies his double vision of human being. To Simon, when the goodness of human nature directs the behavior of human, man is heroic, as we have once created so many marvels by our nature; when the evil of human nature overwhelms us, man is sick. Simon has sensed not only the history and reality of human being, but also the philosophy of human nature, while other boys haven't.

With the knowledge of human evil, Simon seems to have consigned himself to the fate as Christ has done. When the boys are confused about the beast of air, Simon is the real skeptic and he suggests "I think we ought to climb the mountain". (William Golding: 142) What's more important is that Simon alone with his inner vision climbs the mountain to explore the evil without any awareness of losing his life or anything. It is his belief in spiritual reality that diminishes his fear of death, and he enters the dark forest without any fear of strange "beast". Through the dialogue with the lord of the flies, Simon has been aware what is the beast, and has discovered the dead parachutist. Simon has found the truth that the imaginary beast is "harmless and horrible".( William Golding:162) On a deep level, if we recognize the truth of man's evil and purges ourselves from it, the beast is harmless; otherwise it is horrible. Simon ignores the 
threat of the lord of the flies and goes down to give the good news to the boys on the beach, who are having a beast-slaying dance. Before he preaches his truth, Beelzebub's promise is fulfilled; he is killed with tearing of teeth and claws of his companions.

In his martyrdom, Simon meets the fate of all saints. Simon's obsequies are those of hero, saint, martyr, an essentially religious affair. His death occurs while the island world cowers under the lash of a gigantic storm. As we pass from the horror of Simon's murder, from the storm's rage, and the ritual's frenzy, to the absolution of cleansing, healing nature, we pass from the atmosphere of tragedy to the glorification of saint. The typographical device of the dropped line, visibly marking the shift from bloodlust to benediction, signals the diminuendo. It is almost as though, in the atmosphere of uncontaminated serenity that follows, nature were striving to atone for the previous wickedness. Finally, with wonderful impact, presently even the sound of the water was still. Simon's lovingly adorned, meticulously tended corps is reverently received by ocean.

Along the shoreward edge of the shallows, the advancing clearness was full of strange, moonbeam-bodied creatures with fiery eyes. Here and there a larger pebble clung to its own air and was covered with a coat of pearls. The tide swelled in over the rain-pitted sand and smoothed everything with a layer of silver (William Golding: 169).

Never is a god more appropriate than to this scene. Simon's coarse hair is dressed with brightness, the line of his cheek is silvered, and the turn of his shoulder becomes sculpted marble. In death Simon becomes a new creation, a work of art, and then "softly, surrounded by a fringe of bright, inquisitive creatures, itself a silver shape beneath the steadfast constellation, Simon's bright body moved out towards the open sea"(William Golding:170). The beauty of the sea and the power of the cosmos convert the human horror of Simon's murder into a scene of tranquility and dignity. It is difficult not to recognize the hint of a resurrection motif here, for the hero is carried through the water to his apotheosis.

Simon does not successfully tell the boys truth, but Golding does give reader enlightenment and a warning through Simon. The enlightenment is that the innate goodness is the fundamental way of saving the world and the warning is that people are sick. Only if people had been aware of these, the world would avoid killing and destruction in the atomic and nuclear war nowadays and in future.

Apart from the above main characters, Roger is the representative of brutality and terrorism at their extreme; the little ones embody the mass; the naval office stands for the adult people who are participating in the war. All these people with symbolic significance attribute to the greatness and success of the novel.

\section{References}

Alastair Niven. (1989). William Golding: Lord and the Flies, York Notes Series.Beijing: World Publishing Corporation, $\mathrm{p} 48$.

James R. Baker. (1988). Critical Essays on William Golding. Bosten: G.K. Hall \& Co. p 23.

Kirstin Olsen. (2000). Understanding Lord of the Flies: a student casebook to issues, sources and historical documents. Westport: Greenwood Press, p 14.

William Golding. (1958). Lord of the Flies. London: Faber and Faber Ltd. 